\title{
EFFECT OF USING CORN DISTILLER'S DRIED GRAINS WITH SOLUBLES IN BROILER DIETS WITHOUT OR WITH ADDING GALZYM ON GROWTH PERFORMANCE AND SOME PHYSIOLOGICAL PARAMETERS \\ Dorra, Tork, M. I.; Z. M. Kalaba and M. E. E. Younis \\ Poultry Production Dept., Fac. of Agric., Mans. Univ., Egypt
}

\begin{abstract}
The present study was carried out to investigate the effect of using $10 \%$ and $20 \%$ corn distiller's dried grains with solubles (CDDGS) as partial replacement for yellow corn and soybean meal with or without adding $0.05 \%$ Galzym powder on productive performance, some blood plasma parameters and the immune response of broiler chicks. A total number of 240 day-old, unsexed broiler chicks were randomly assigned to six treatments 40 chicks each. The first group was fed basal (starter and grower-finisher) diets without supplements and considered as control (T1) group, the second group was fed as T1 plus $0.05 \%$ Galzym (T2), the third group was fed $10 \%$ CDDGS (T3), the $4^{\text {th }}$ group was fed as T3 plus Galzym addition, the $5^{\text {th }}$ group was fed $20 \%$ CDDGS (T5), the $6^{\text {th }}$ group was fed as T5 plus Galzym (T6).

The obtained results showed that final live body weight values increased by CDDGS replacement. The highest final live body weight, total feed intake and total body weight gain values were recorded by the birds fed $20 \%$ CDDGS level with Galzym as compared to other experimental treatments. Also, the lowest total feed conversion values were recorded for the birds fed 20\% CDDGS plus Galzym as compared to other experimental birds. The results showed that there were significant increase in the experimental treatments in plasma total protein and total triglycerides values compared with the control treatment. Moreover, there were insignificant increases in total cholesterol values compared with the control group. Also, there were significant decreases in plasma inorganic phosphorus values as compared to the control treatment. The specific immunity against avian influenza disease virus (AIDV) titer was significantly increased when using $10 \%$ CDDGS with Galzym supplementation in the diets after vaccination as compared to other experimental samples. Also, there were insignificant differences in the Newcastle disease virus (NDV) titer after vaccination among all the experimental treatments.

It is concluded that using CDDGS up to $20 \%$ in broiler diets as partial replacement for yellow corn and soybean meal with or without Galzym supplementation improved growth performance of broiler chicks and enhanced the specific immunity against avian influenza disease virus titer, with no adverse effects on their physiological blood parameters.
\end{abstract}

Key words: Broiler, corn distiller's dried grains with solubles

\section{INTRODUCTION}

Recently, high ingredient costs have led to increasing use of coproduct ingredients in poultry such as CDDGS. Corn Distiller's Dried Grains with solubles (CDDGS) is a co-product after corn starch is fermented for ethanol fuel using dry milling technology Davis (2001) and Butzen and Haefele (2008). It contains all the nutrients remaining in the corn kernel in which the non-starch nutrients are three times concentrated of the original 
Tork, M. I. Dorra et al.

nutritional value of the corn Davis (2001). Hence, CDDGS contains good source of energy, protein and available phosphorus. With the new processing technologies used in recently-built ethanol plants the nutrient profiles of CDDGS have improved and such CDDGS became available for feeding livestock Noll et al. (2007). One of the biggest challenges in using CDDGS as a source of feed is the variation in nutrient concentrations among CDDGS sources and processing plants Cromwell et al. (1993); Spiehs et al. (2002) and Belyea et al. (2004). The high variability among sources was found especially for concentrations of lysine, methionine and minerals Swiatkiewicz and Koreleski (2008). Fastinger et al. (2006) noted that lysine concentration in five different sources of CDDGS ranged from 0.48 to $0.76 \%$. These differences could be attributed to variation in original grain composition, efficiency of starch fermentation during ethanol production and fermentation scale up, different amount of solubles added back, and drying procedures Swiatkiewicz and Koreleski (2008). In addition, CDDGS contains considerable amount of antinutritional factors such as arabinoxylan Kim et al. (2008) and its high fiber 8.8 to $10.2 \%$ could affect the nutrient utilization in poultry and so limit the CDDGS dietary inclusion. The high fiber can also decrease the nutrient digestibility of other dietary ingredients Spiehs et al. (2002). Earlier work showed that feeding low level of CDDGS (approximately $5 \%$ ) in broiler diets improved weight gains Day et al. (1972) and a higher inclusion level was not detrimental to growth performance when metabolizable energy and lysine level were constant and sufficient in the broiler diets Waldroup et al. (1981) Parsons et al. (1983). More recently, the 'new generation of CDDGS was utilized in poultry feed; incorporating $5 \%$ CDDGS in broiler starter diet and up to 12 to $15 \%$ in grower diet had no negative impact on production parameters Lumpkins et al. (2004) and Choi et al. (2008) while higher inclusion levels at 15 to 25\% CDDGS decreased dressing percentage and breast meat yield Wang et al. (2007) and Lumpkins et al. (2003).

Enzyme use is well documented across different types of poultry diets. Example papers on amylase Ritz et al. (1995) and Jiang et al. (2008), protease Ghazi et al. (2002 and 2003) and Wang et al. (2008), xylanase Mathlouthi et al. (2002) and Cowieson (2005), beta-glucanase Mathlouthi et al. (2002), mixes of two or more of the aforementioned activities Pettersson and Åman (1992); Vranješ et al. (1994); Zanella et al. (1999); Hong et al. (2002); Mathlouthi et al. (2002); Meng et al. (2005) and Cowieson and Ravindran (2008a, b) as well as phytase Onyango et al. (2005) Liu et al. $(2008 a, b)$ are among the many that can be found in the Scientific literature. However, trials often examine one type of enzyme in isolation. For example, many of the published phytase papers do not examine relationships between phytase and various carbohydrases or proteases in practical diets. It would seem logical that combinations of phytase, nonstarch polysaccharidases NSPases or other activities may provide a benefit in practical diets.

Avian influenza viruses (AIV) are type A influenza viruses and belong to the Orthomyxoviridae family. They can be classified according to the antigenicity of its surface proteins haemagglutinin $\mathrm{H}$ and neuraminidase $\mathrm{N}$. 
Currently $16 \mathrm{H}$ (H1-16) and 9N (N1-9) subtypes have been described in avian species Fouchier et al. (2005). Furthermore the subtypes can be classified on the basis of their pathogenicity in chickens after intravenous inoculation. In Egypt, since early 2006, high pathogenicity avian influenza H5N1 has continued to spread in the domestic poultry farms despite the implementation of quarantine, improved biosecurity and vaccination Peyre et al. (2009) and World health organization (2010). The antibody responses upon AIV vaccination are generally higher in chickens than in other poultry species Higgins (1996). The majority of current Al vaccines have been inactivated whole-virus vaccines Swayne et al. (2003). As well, The insufficient efficacy of the current $\mathrm{H} 5$ vaccines to protect chickens against the newly emerging 2.2.1 variant highly pathogenic Al H5N1 strains in Egypt have been recently obtained Kim et al. (2010). Whilst, Brugh and Stone (1986) stated that vaccination of broilers would not be suitable, although research has shown great benefit to the day-old immunization of broilers with killed oil emulsion Al vaccine. Newcastle disease is caused by avian paramyxovirus type of the family Paramyxoviridae, whereas Al is caused by type A influenza virus of the family Orthomyxoviridae Alexander (2000) and Swayne and Suarez (2000). The highly virulent forms of ND and Al are on list A of the Office International des Epizooties Swayne and King (2003). Control of ND virus in poultry is mainly dependent on both live and inactivated virus vaccines Gallili and BenNathan (1998).

The objective of the study is to examine the effects of Corn Distiller's Dried Grains with Solubles as partial replacement for yellow corn and soybean meal with or without Galzym addition (Enzyme Preparation) on growth performance, some blood plasma parameters, specific immunity against Avian Influenza Disease Virus (AIDV) and the Newcastle Disease virus (NDV).

\section{MATERIALS AND METHODS}

The present study was carried out at the Agriculture Research and Experiments Center; Faculty of Agriculture, Mansoura University, Egypt, during the period from September to October, 2012.

\section{Birds and management:}

Two hundred and forty one day-old of unsexed commercial-type Cobb 500 broiler chicks were used in this experiment from 10 to 45 days of age. The initial body weight of one day old chicks was about $49 \mathrm{~g}$. They were randomly divided into six experimental treatments each of which was assigned to four replicates containing 10 chicks each. Chicks in all treatments were kept under similar conditions of management. Artificial lightning was provided $24 \mathrm{~h}$ daily during the whole experimental period. From post hatching to ten days-old, all chicks were fed a commercial starter ration containing 22 $\%$ crude protein and $3000 \mathrm{Kcal} . \mathrm{ME} / \mathrm{Kg}$ diet then the chicks fed growerfinisher diets ad Libitum containing $19 \%$ crude protein and $3100 \mathrm{Kcal} . \mathrm{ME} / \mathrm{Kg}$. 


\section{Experimental design:}

Chicks were allotted to the following dietary treatments in the starter and grower-finisher diets; T1: control diets, T 2: T1 + $0.05 \%$ Galzym powder, T3: diets containing $10 \%$ CDDGS, T4: T3 $+0.05 \%$ Galzym powder, T5: diets containing $20 \%$ CDDGS, T6: T5 $+0.05 \%$ Galzym powder. The composition and calculated analysis of the experimental diets are shown in (Table1). CDDGS was provided by El -dakakahlia for poultry production company and Galzym powder was provided by Arab trade company (Tex Biosciences limited-India) each kilogram contained; Cellulase 100.000.000 U, Amylase $125.000 \mathrm{U}$, Arabinase $20.000 \mathrm{U}$, Pectinase $30.000 \mathrm{U}$, Protease 15.000 U, Lipase 10.000 U, Xylanase 1.500.000 U, $\alpha$ - Galactosidase 10.000 $\mathrm{U}, \beta$ - Glucosidase $10.000 \mathrm{U}$ and Sodium Benzoate $50 \mathrm{mg}$. At the 10th day of age three chicks from each treatment were wing banded. Therefore, blood samples were taken from brachial vein of each chick before and after vaccination. Blood samples were collected in heparinized tubes, centrifuged immediately at 4000 r.p.m for $10 \mathrm{~min}$. and plasma were decanted in Ependorfer tubes and frozen rapidly at $-20^{\circ} \mathrm{C}$ until the time of analysis.

\section{Studied traits:}

Final live body weight (LBW), total body weight gain (TBWG), total feed intake (TFI) and total feed conversion ratio (TFCR) were determined during the experimental period. Plasma total protein, cholesterol, triglycerides and inorganic phosphorus were determined by using commercial kits (BIOADWIC, Quimica clinging aplicada S.A., Human Gesellschaft fur Biochemica und Diagnostica GmbH Max-planck-Ring21-D-Wiesbaden-Germany, analyzed colorimetrically with a spectronic ${ }^{\circledR} 207$ ) according to Doumas (1975), Allain et al. (1974), Sidney and Barnard (1973) and Using the AOAC (1984) procedure, respectively. The titer of $\mathrm{HI}$ against AIDV was determined by $\mathrm{HI}$ test according to Tian et al. (2005) and Kumar et al. (2007). HI titers log 2 to avian influenza using $4 \mathrm{HA}$ units of H5N2 ift antigens. HI titers to Newcastle disease using 4HA units of Lasota Jovac NDV, Lasota strain propagated in embryonated chicken eggs.

\section{Statistical analysis:}

Data were statistically analyzed and computed using SAS (1990) by the application of the least square producer. Tests of significance for the differences among treatments means were done according to Duncan's multiple range test procedure Duncan (1955).

\section{RESULTS AND DISCUSSION}

Growth performance: The results showed that at $45^{\text {th }}$ day of age there were significant increase $(P \leq 0.0001)$ on final live body weight (LBW) due to different CDDGS levels as partial replacement, $(P \leq 0.01)$ due to Galzym addition to diets as compared to control birds. Also, the highest final LBW values were recorded by the birds fed $20 \%$ CDDGS followed by those fed Galzym addition then those fed $10 \%$ CDDGS to diets as compared to control birds (Table2). These results are in agreement with Lumpkins et al. (2004) who found that $15 \%$ of DDGS improved the growth performance of broiler 
chicks from 0 to 18 days of age after feeding iso-caloric diets and no difference in growth performance from 0 to 42 days of age after feeding isocaloric and iso-protein diets containing 12\% DDGS. Likewise, Waldroup et al. (1981) showed that inclusion of $25 \%$ DDGS into broiler diets with the ME content held constant could be used without reduction in body weight in which the energy content was allowed to decline as the level of DDGS was increased. Also, Wang et al. (2007a,b.c) suggested that good quality DDGS could be used in starter and grower broiler diets at levels of 15 to $20 \%$ CDDGS, with even higher levels of $30 \%$ CDDGS in the finisher diet. Although even higher levels of the new generation DDGS could be used in broiler diets without any negative impact on body weight. As well, Shurson (2003) observed that growth rate and survivability improved in broiler chicks when fed diets containing $10 \%$ DDGS from 14 to 38 days of age.

Table 1: Composition and calculated analysis of the starter and growerfinisher diets

\begin{tabular}{|c|c|c|c|c|c|c|}
\hline \multirow[b]{2}{*}{ ingredients } & \multicolumn{2}{|c|}{ control } & \multicolumn{2}{|c|}{$10 \%$ CDDGS } & \multicolumn{2}{|c|}{$20 \%$ CDDGS } \\
\hline & starter & $\begin{array}{l}\text { Grower- } \\
\text { finisher }\end{array}$ & starter & $\begin{array}{l}\text { Grower- } \\
\text { finisher }\end{array}$ & starter & $\begin{array}{l}\text { Grower- } \\
\text { finisher }\end{array}$ \\
\hline Yellow corn & 60 & 71,0 & 56 & $4 \pi$ & 52 & $0 \wedge$ \\
\hline Soybean meal (44 \%) & 27.5 & $17, V$ & 19.5 & $1 \mathrm{TH}, \mathrm{V}$ & 11 & $\wedge$ \\
\hline Corn gluten meal $(62 \% \mathrm{CP})$ & 8.4 & $1 \cdot, \mathrm{V}$ & 10.2 & 9 & 12 & 9 \\
\hline CDDGS & 0 & . & 10 & 1. & 20 & r. \\
\hline Dicalcium phosphate & 2 & t & 2 & r & 2.2 & $Y, Y$ \\
\hline Limestone & 1.2 & $1, r$ & 1.3 & $1, \pi$ & 1.5 & 1,0 \\
\hline Common salt & 0.3 & $\cdot, r$ & 0.3 & $\cdot, \Gamma$ & 0.3 & $\cdot, r$ \\
\hline Vit. \& min. Premix* & 0.3 & $\cdot, \Gamma$ & 0.3 & $\cdot, \Gamma$ & 0.3 & $\cdot, \Gamma$ \\
\hline DL- Methionine & 0.1 & $\cdot, .0$ & 0.1 & $\cdot, 10$ & 0.2 & $\cdot, Y$ \\
\hline Lysine- HCL & 0.2 & $\cdot, 10$ & 0.3 & $\cdot, Y_{0}$ & 0.5 & $\cdot, 0$ \\
\hline Total & 100 & $1 \cdots$ & 100 & $1 \cdots$ & 100 & $1 \cdots$ \\
\hline \multicolumn{7}{|c|}{ Calculated analysis (air dry basis) } \\
\hline $\mathrm{ME} ; \mathrm{kcal} / \mathrm{kg}$ & $r q \leq V$ & $r \cdot V t$ & $r \ldots$ & T. T. & $r \cdot \Sigma q$ & $r \cdot v i$ \\
\hline $\mathrm{CP} ; \%$ & TY,70 & 19,97 & rY,79 & $19,9 V$ & YY,TT & 19,99 \\
\hline EE; \% & $r, V I$ & $r$ & $r, 70$ & $\Gamma, \wedge \varepsilon$ & $\varepsilon, 01$ & $\varepsilon, V$ \\
\hline CF; \% & r, ro & $r, \wedge r$ & r, ro & $r, .9$ & r, & $r, Y)$ \\
\hline $\mathrm{Ca} ; \%$ & 1 & 1 & 1 & $\cdot, 99$ & $1, .9$ & 1,1 \\
\hline Available $\mathrm{P} ; \%$ & $\cdot, \leqslant V$ & $\cdot, \leqslant 0$ & $\cdot, \leqslant 0$ & $\cdot, \varepsilon \varepsilon$ & $\cdot, \leqslant 7$ & $\cdot, \leqslant 0$ \\
\hline Lysine; \% & $1,1 \varepsilon$ & $\cdot, 10$ & 1 & $\cdot, \Lambda Y$ & $\cdot, 9 \varepsilon$ & $\cdot, 10$ \\
\hline Methionine; \% & $\cdot, 0$ & $\cdot, \varepsilon \varepsilon$ & $\cdot, \Sigma V$ & $\cdot, \leqslant \wedge$ & $\cdot, 0 \leqslant$ & $\cdot, \varepsilon \wedge$ \\
\hline Meth. \& cystine; \% & $\cdot, \wedge 9$ & $\cdot, 1 \vee q$ & $\cdot, \lambda r$ & $\cdot, 199$ & $\cdot, \wedge \varepsilon$ & $\cdot, v \varepsilon$ \\
\hline
\end{tabular}

${ }^{*}$ Each $3 \mathrm{~kg}$ premix contains: Vit. A, 12.000.000 IU; Vit. D3, 2.500 .000 IU; Vit. E, 10 g; Vit. K $2.5 \mathrm{~g}$; Vit. B2, $5 \mathrm{~g}$; Vit. B6, $1.5 \mathrm{~g}$; Vit. B12, $10 \mathrm{mg}$; Biotin, $50 \mathrm{mg}$; Folic acid, $1.0 \mathrm{~g}$; Nicotinic acid, 30 mg; Pantothenic acid, 10 g; Antioxidant, 10 g; $\mathrm{Mn}, 60$ g; Cu, 10 g; Zn, 55 g; Fe, 35 g; I, $1.0 \mathrm{~g}$; Co, $250 \mathrm{mg}$ and Se, $150 \mathrm{mg}$.

Also, Day et al. (1972) and Couch et al. (1957) showed that DDGS have been used for broilers for many years, but very low level $5 \%$ of DDGS has been added in the broiler diet while the improvements in body growth rate and other characteristics were observed in early studies that incorporated DDGS to broiler and turkey diet. Likewise, Potter (1966) found that isonitrogenous broiler diets with $20 \%$ DDGS supported performance 
equivalent to control diets when fed to broiler up to 8 weeks of age. Likewise, Choi et al. (2008) found that using of 5\% CDDGS in broiler starter diet and up to $15 \%$ in grower diet had no negative impact on production parameters. Also, the results showed that there were insignificant effects $(P>0.05)$ on final LBW values of the interaction between CDDGS levels and Galzym addition to diets (Table2). Also, the highest final LBW values were recorded by the birds fed $20 \%$ CDDGS with Galzym addition to diets as compared to other experimental birds.

These results are in agreement with those findings by Shalash et al. (2009) who found that adding preparation enzymes to CDDGS diets improved live body weight. Increased final live weight by addition of enzymes is agreed with many previous findings Richter et al. (1999); Augelovicova and Michalik (1997); Al-Bustany (1996) and Salobir et al. (1995) they concluded that improved feed utilization for exogenous enzyme was responsible for increased live body weight in broiler on similar level of dietary nutrient concentration. In turkeys, Noll and Brannon (2006) reported that birds fed $20 \%$ DDGS was not different in productive performance values compared with corn-soybean control. As well, Wyatt et al. (1997) and Pack et al. (1998) cited that supplementing corn based diets with enzymes produced significant positive responses to growth performance. However, the results showed that there were significant effects $(P \leq 0.0001)$ from $10^{\text {th }}$ to $45^{\text {th }}$ day of age, on total feed intake (TFI) values when using different CDDGS levels as partial replacement, $(P \leq 0.05)$ due to Galzym addition to diets as compared to control birds Table 2. The highest TFI values were recorded in the birds fed $20 \%$ CDDGS followed by those fed Galzym addition then those fed $10 \%$ CDDGS as compared to control birds. These results are in agreement with Onifade and Babatunde (1998) who reported increased feed intake with increasing levels of dietary Brewers Dried Grain (BDG). Likewise, Waldroup et al. (1981) who reported that inclusion $25 \%$ of DDGS into broiler diets with the ME content held constant could be used without reduction in feed utilization. Also, Lumpkins et al. (2004), Wang et al. (2007), Choi et al. (2008) and Widyaratne and Zijlstra (2007) showed that dietary levels from 0 to $20 \%$ CDDGS had no significant effect on FI. On the contrary, Cromwell et al. (1993) concluded that chicks fed the darkest-colored, burnt-smelling DDGS resulted in decreased $\mathrm{FI} 13 \%$ as compared to chicks fed the lightest-colored DDGS. Also, there were insignificant differences $(P>0.05)$ on TFI values of the interaction between different levels of CDDGS and Galzym addition to diets (Table2). Also, the highest TFI values were recorded by the birds fed 20 $\%$ CDDGS with Galzym addition to diets as compared to other experimental birds. Also, the results showed that the highest total body weight gain (TBWG) values were recorded by the birds fed $20 \%$ CDDGS followed by those fed Galzym addition then those fed $10 \%$ CDDGS to diets as compared to control birds (Table2). However, there was insignificant effect $(P>0.05)$ on TBWG values of the interaction effect between the birds fed different levels of CDDGS and Galzym addition to diets (Table2). Also, the highest TBWG values were recorded in the birds fed $20 \%$ CDDGS with Galzym addition to diets as compared to other dietary treatments. 
These results are in agreement with Arce et al. (2010) who reported that adding protease and xylanase enzymes in broilers diets containing maize, soybean meal and DDGS yielded the best results in terms of broiler performance. As well, Parsons et al. (1983) found that DDGS can replace up to $40 \%$ soybean if lysine level in broiler diet can meet the requirement. Likewise, Shurson (2003) observed improved productive performance rate and survivability in broiler chicks when fed diets containing 10\% DDGS from 14 to 38 days of age. On the other hand, Awad et al. (2011) indicated that TBWG values were insignificantly improved by feeding different CDDGS levels to diets compared with those birds fed control diet from 1 to 84 days in Domyati ducklings. Likewise, Wang et al. (2007a, b, c) found that higher levels of the new generation DDGS could be used in broiler diets without any negative effects on body weight. However, Lumpkins et al. (2004) and Choi et al. (2008) showed that more recently, the 'new generation' of CDDGS was utilized in poultry feed; incorporating 5\% CDGS in broiler starter diets and up to $15 \%$ in grower diets had no negative effects on productive performance. Also, Lumpkins et al. (2004) focused on feeding inclusion rates of $0,6,12$, and $18 \%$ DDGS to young broiler chicks. They found that LBW and FI were not affected by feeding $12 \%$ DDGS, but BWG and FI were reduced when broilers were fed $18 \%$ CDDGS, most likely due to an amino acid deficiency in the starter diet. Also, due to the high fiber content and low amino acid digestibility of DDGS, feeding high levels 25 to $30 \%$ of DDGS to starter broilers is not recommended. On the contrary, Waldroup et al. (1981) found that DDGS can be used at $25 \%$ level without any adverse effects on BWG as long as metabolizable energy level was consistent. However, Dale and Batal (2003) used 0, 6, 12 and 18\% DDGS in broiler diets and reported that $12 \%$ DDGS resulted in a slight decrease in performance during the starter period while $18 \%$ DDGS had a negative impact on body weight. Also, Wang et al. (2008) found that at 14 days post hatch, the higher levels of DDGS numerically reduced the LBW at 35,42 and 49 days, being reduced gradually more than $30 \%$ DDGS. They suggested that once beyond the starter and grower periods from 1 to 22 days, chicks could efficiently use not more than $20 \%$ DDGS into broiler rations. Also, Widyaratne and Zijlstra (2007) found that diets with $20 \%$ wheat DDGS had a decreasing trend on performance and suggested to use $15 \%$ wheat DDGS for broilers without negative effects on performance. Also, the obtained results showed that there were significant effects $(P \leq 0.0001)$ during the experimental period on total feed conversion ratio (TFCR) values while there were insignificant differences $(P>0.05)$ due to Galzym addition to diets (Table2). Also, the best TFCR values were recorded by the birds fed $20 \%$ CDDGS followed by those fed diets with enzyme preparation as compared to control birds but the birds fed $10 \%$ CDDGS recorded the highest TFCR values. The effect of interaction between CDDGS and Galzym addition levels was not significant on TFCR (Table2). 
Tork, M. I. Dorra et al.

Table 2: Effects of CDDGS and Galzym levels on broiler productive performance from $10-45$ days of age

\begin{tabular}{|c|c|c|c|c|}
\hline $\begin{array}{c}\text { Productive } \\
\text { performance } \\
\text { measurements }\end{array}$ & $\begin{array}{c}\text { Final live } \\
\text { body weight } \\
(\mathrm{g})\end{array}$ & $\begin{array}{l}\text { Total feed } \\
\text { intake }(g)\end{array}$ & $\begin{array}{c}\text { Total body } \\
\text { weight gain (g) }\end{array}$ & $\begin{array}{c}\text { Total feed } \\
\text { conversion } \\
\text { ratio }\end{array}$ \\
\hline \begin{tabular}{|c|} 
Age \\
Main effect of CDDGS \\
(A)
\end{tabular} & $45^{\text {th }}$ day & 10 - 45 days & $10-45$ days & $10-45$ days \\
\hline \begin{tabular}{|l|l|} 
Control(0\%CDDGS) & 1
\end{tabular} & $2170^{c}$ & $4839^{c}$ & $2025^{c}$ & $2.38^{b}$ \\
\hline $10 \%$ CDDGS & $2289^{b}$ & $5120^{b}$ & $2140^{b}$ & $2.39^{b}$ \\
\hline $20 \%$ CDDGS & $2524^{a}$ & $5486^{a}$ & $2368^{a}$ & $2.32^{a}$ \\
\hline SEM & 0.01 & 0.03 & 0.01 & 0.004 \\
\hline Significance level & $\pi \approx \pi \approx$ & & & \\
\hline \multicolumn{5}{|l|}{$\begin{array}{l}\text { Main effect of Galzym } \\
\text { (B) }\end{array}$} \\
\hline \begin{tabular}{|l|l} 
Control(0\%Galzym) & 1
\end{tabular} & $2296^{b}$ & $5107^{b}$ & $2148^{b}$ & 2.38 \\
\hline $0.05 \%$ GALZYM & $2357^{a}$ & $5191^{a}$ & $2207^{a}$ & 2.35 \\
\hline SEM & 0.01 & 0.02 & 0.01 & 0.003 \\
\hline Significance level & . & & 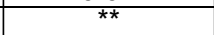 & NS \\
\hline \multicolumn{5}{|l|}{$A^{*} B$ Interaction } \\
\hline 1 & 2158 & 4739 & 2012 & $2 . r 4$ \\
\hline 1 & 2185 & 4939 & 2040 & 2. $\leqslant Y$ \\
\hline 1 & 2261 & 5116 & 2113 & 2. $\leqslant Y$ \\
\hline 2 & 2318 & 5124 & 2168 & $2 . T^{4}$ \\
\hline 1 & 2474 & 5464 & 2320 & 2.36 \\
\hline 2 & 2573 & 5508 & 2415 & 2.28 \\
\hline SEM & 0.02 & 0.04 & 0.02 & 0.006 \\
\hline Significance level & NS & NS & NS & NS \\
\hline
\end{tabular}

(a-c) means with the same letter in each column in each category are not significantly different at $p \leq 0.05 \mathrm{NS}=$ not significant at $P>0.05 \quad{ }^{*}$ significant at $p \leq 0.05$

** significant at $p \leq 0.01 \quad * * * *$ significant at $p \leq 0.0001$

These results are in agreement with Ghazalah et al. (2012) who showed that feeding broiler chicks on diets containing different levels of DDGS up to $60 \%$ as replacement for soybean meal with enzyme supplementation improved feed conversion values in laying hen diets. On the contrary, Wang et al. (2007a, b, c) formulated diets based on digestible amino acid levels and found that dietary inclusion up to $25 \%$ of CDDGS resulted in poorer FCR. Whilst, Amani et al. (2012) showed that BWG did not differ among diets containing $0,10,20$ or $30 \%$ DDGS while FCR was significantly $(P \leq 0.05)$ improved for rabbits fed $10 \%$ and $20 \%$ CDDGS 1.97 and 1.94 comparing to control one 2.09. As well, It is worthy to note that there was no mortality allover the experimental period; as broiler chicks fed diets containing different levels of DDGS. These results are in agreement with those findings by Youssef et al. (2008), Shalash et al. (2009) and Masadeh et al. (2010) who found that there was no mortality due to using DDGS in broiler chick diets. Likewise, More recently, the 'new generation' of CDDGS was utilized in poultry feed; incorporating 5\% CDGS in broiler starter diet and up to $15 \%$ in grower diet had no negative impact on production parameters found by Lumpkins et al. (2004) and Choi et al. (2008). 
Some plasma constituents:

Total protein: There are significant differences among treatments $(P \leq 0.01)$ in blood plasma total protein (TP) values (Table3). The birds fed basal diets and those fed $20 \%$ CDDGS recorded the highest values than those fed $10 \%$ CDDGS into broiler rations. These results are in agreement with Kaya and Tarkan (2012) who found that the addition of DDGS in different amounts 5, 10 and $15 \%$ created statistically significant differences $(P<0.05)$ between the total protein values in blood serum of broiler chicks. On the other hand, there were insignificant differences $(P>0.05)$ due to Galzym supplementation to diets (Table3). These results are in agreement with Qota et al. (2002); Shakmak (2003) and Al-Harthi (2006) who found that cell-wall degrading enzymes and/or phytase supplementation had no adverse effect on plasma biochemical constituents of broiler chicks. However, the obtained results of blood plasma total protein values were lower than those found by Lu and Chen (2005) but higher than those found by Kaya and Tarkan (2012).In ducks, Awad et al. (2011) found that plasma total protein values increased by feeding diets containing $30 \%$ DDGS to Domyati ducklings. As well, Tanaka et al. (2008) reported that plasma total protein level was significantly increased after the commencement of DDGS feeding in lactating diary cows. Concerning the interaction effects, the present results showed that TP recorded the highest values in the birds fed 20\% CDDGS with or without Galzym supplementation to diets. However, there were non significant differences $(P>0.05)$ in plasma TP values due to the interaction effects between CDDGS and Galzym levels (Table3). These results are in close agreement with those found by Lu and Chen (2005) who found that TP was not significantly affected by feeding diets contained 10 and $20 \%$ DDGS to domestic colored broiler chickens. However, Bor-Ling et al. (2011) found that TP was not impacted by the dietary treatments $0,6,12$ and $18 \%$ DDGS of laying hens. Likewise, Gabr et al. (2008) found that TP was not significantly affected by feeding diets contained 10,15 and 20\% DDGS to rabbits. On the contrary, Ghazalah et al. (2012) demonstrated that TP decreased when laying hens were fed diets contained $75 \%$ DDGS.

2- Total cholesterol: The obtained results showed that there were significant differences $(P \leq 0.001)$ in blood plasma total cholesterol due to different dietary treatments (Table3). While, the birds fed 20\% CDDGS recorded the highest values than other experimental treatments. These results are in agreement with the findings by Bor-Ling et al. (2011) who found that plasma total cholesterol content was significantly increased when $12 \%$ or $18 \%$ DDGS diets were used for laying hens. However, the addition of Galzym increased significantly $(P \leq 0.001)$ plasma total cholesterol levels. These results are in agreement with Mancini and Parillo (1991); Pettersson and Aman (1992) and Sutton et al. (1985) who found that plasma total cholesterol increased numerically according to enzymes supplementation to the diets. On the contrary, the results of the interaction effects between CDDGS and Galzym levels showed insignificant differences $(P>0.05)$ among all the experimental treatments (Table3). Also, Kaya and Tarkan (2012) indicated that the addition of different levels of DDGS did not affect plasma total 
cholesterol values in broiler chicks. Likewise, Shalash et al. (2009) reported that blood plasma total cholesterol content were not significantly affected by feeding diet contained $12 \%$ DDGS in broiler chicks. However, the values of this study were lower than those found by Kaya and Tarkan (2012) and BorLing et al. (2011). On the other hand, Awad et. al. (2011) found that plasma total cholesterol was decreased by $9.19,18.10$ and $20.76 \%$ for the groups fed diet contained 10, 20 and $30 \%$ DDGS as compared to control, respectively in Domyati laying ducks. Also, Gabr et al. (2008) found that cholesterol was not significantly affected by feeding diets contained 10, 15 and $20 \%$ DDGS in rabbits diets. However, Gurung et. al. (2009) found that Serum cholesterol concentrations increased linearly $(p<0.001)$ with increasing levels of DDGS in Spanish male goats. On the other hand, Jia et. al. (2009) found that addition of sorghum DDGS to the diets reduced plasma cholesterol in hamsters.

Table 3: Effects of dietary CDDGS and Galzym levels on broiler blood plasma parameters

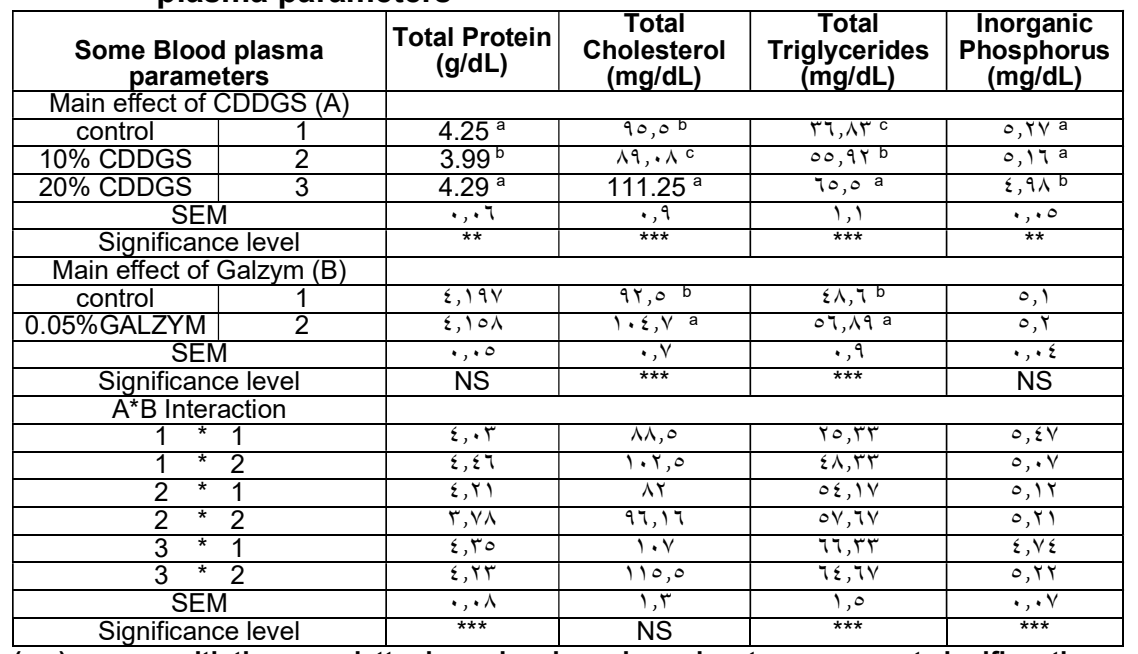

(a-c) means with the same letter in each column in each category are not significantly different at $p \leq 0.05 \mathrm{NS}=$ not significant at $P>0.05 \quad{ }^{* *}$ significant at $p \leq 0.01$ $* * *$ significant at $p \leq 0.001$

3- Total triglycerides: The obtained results showed that there were significant differences $(P \leq 0.001)$ among treatments in blood plasma total triglycerides when using different CDDGS levels as partial replacement or Galzym addition to diets (Table3). Also, the interaction has significant effects on plasma total triglycerides (Table3). The highest mean of blood plasma total triglycerides values were recorded in the birds fed $20 \%$ CDDGS with or without Galzym supplementation. On the contrary, Lu and Chen (2005) found that blood plasma triglyceride was not significantly influenced by the dietary CDDGS treatments. The obtained results were lower than those found by Kaya and Tarkan (2012) and Bor-Ling et al. (2011), but higher than those 
found by Lu and Chen (2005). Kaya and Tarkan (2012) demonstrated that blood plasma total triglycerides values were lower than control in broiler fed 5, 10 and $15 \%$ DDGS. Also, Kaya and Tarkan (2012) indicated that plasma total triglycerides values were lower than the total triglycerides values found in the blood serum of ducks fed diets supplemented with $0,6,12$ and $18 \%$ DDGS by Awad et al. (2011). However, Bor-Ling et al. (2011) found that plasma total triglyceride was not impacted by the dietary treatments $0,6,12$ and $18 \%$ DDGS in laying hens. Likewise, Lu and Chen (2005) found that the blood plasma triglyceride was not significantly influenced by the dietary treatments 10 or $20 \%$ DDGS. On the contrary, Kimura (2005) found that the blood plasma triglycerides concentration clearly decreased after feeding DDGS.

4- Inorganic phosphorus: The results indicated that there were significant differences $(P \leq 0.01)$ in plasma phosphorus level when using different CDDGS levels (Table3). Also, significant differences ( $P \leq 0.001)$ were recorded for the interaction between the different levels of CDDGS and Galzym supplementation to diets (Table3). These results showed that there were significant decrease in blood plasma inorganic phosphorus values in the birds fed $20 \%$ CCDDGS as compared to the control birds (Table 3 ). These results are in agreement with Shalash et al. (2009) who reported significantly increase $(p<0.0001)$ in plasma phosphorus values among the different treatments. Also, Martinez-Amezcua et al. (2004) noted a substantial variability in phosphorus bioavailability among nine samples, ranging from 69 to $102 \%$ relative to $\mathrm{KH} 2 \mathrm{PO} 4$ and reported that increasing heat processing of DDGS may increase the bioavailability of phosphorus in DDGS. However, Leytem et al. (2008) found that the apparent retention of both nitrogen and phosphorus decreased linearly with increasing DDGS inclusion from 0 to $20 \%$ in the diets. They added that, at the greatest DDGS inclusion $20 \%$ rate there was a corresponding decrease in nitrogen digestibility by $19 \%$ and phosphorus digestibility by $23 \%$ compared with the control diet. However, the mean values of plasma inorganic phosphorus were lower than those found by Shalash et al. (2009) but higher than those obtained by Bor-Ling et al. (2011). Also, Viveros et al. (2002) found that Phytase supplementation to a low nonphytate phosphorus diets increased plasma phosphorus level. As well, Ali et al. (2006a) found that the addition of enzyme preparation to laying hen diet significantly increased plasma phosphorus level. Likewise, Heba (2011) found that plasma phosphorus concentrations increased with increasing DDGS inclusion level in cattle. On the other hand, there were non significant differences $(P>0.05)$ recorded by the effects of Galzym supplementation to diets. These results are in agreement with the findings of Qota et al. (2002); Shakmak (2003) and Al-Harthi (2006) who found that cell-wall degrading enzymes and/or phytase supplementation had no adverse effect on plasma biochemical constituents of broiler chicks.

Immunological traits:

-A- Specific immunity against avian influenza disease virus titer (AIDV): The obtained results showed that there were significant differences ( $P \leq$ 0.001 ) in immune response between treatments as compared to control birds 
(Table4). These results showed that the highest AIDV titers were recorded for the birds fed $10 \%$ CDDGS to diets followed by those fed $20 \%$ CDDGS as compared to the control birds. On the other hand, there were no significant differences $(P>0.05)$ due to adding Galzym addition to diets (Table4). Also, there were no significant differences $(P>0.05)$ in the interaction between the different levels of CDDGS and Galzym supplementation to diets before and after vaccination (Table4). Also, the highest mean of AIDV titers were recorded by the birds fed $20 \%$ CDDGS with Galzym addition to the diets. These results are in agreement with Shalash et al. (2009) who found that specific immunity against avian influenza disease virus of broilers were significant $(p<0.01)$. The mean of AIDV titers values were higher than those found by Shalash et al. (2009). Also, El-Sayed et al. (2011) demonstrated that birds vaccinated with $\mathrm{Al}+\mathrm{ND}$ recorded higher antibody titer against $\mathrm{Al}$ virus at all ages. Likewise, the obtained results revealed that $\mathrm{HI}$ titer values are in agreement with El-Sayed et al. (2011) who found that the geometric mean of $\mathrm{HI}$ titer against $\mathrm{Al}$ virus of experimental broiler chicks vaccinated with $\mathrm{Al}+\mathrm{ND}$ vaccine was $8.20 \log 2$ for all experimented ages. In agreement with these findings, Lebdah and Shahin (2010) who found that the geometric mean of $\mathrm{HI}$ titer of broiler chicks vaccinated at one day-old with $\mathrm{H} 5 \mathrm{~N} 2$ vaccine showed high titer. Likewise, Ellis et al., (2004) stated that the use of killed H5N2 vaccine was able to protect chickens from disease and can reduce virus transmission. Also, these findings agreed with Tian et al. (2005).

However, Swayne et al. (2009) reported that the HI titers will probably be indicative of the level of protection and immunity to avian influenza. Also, Hafez et al. (2010) had shown that HI titer for commercial broiler chicks vaccinated at one day-old ranged from 5.2 to 9 log2 at 32 daysold and from 2.0 to 7.2 log2 at 45 days-old. However the $\mathrm{HI}$ titer for the chicks vaccinated at 7 days-old ranged from 2.0 to $3.0 \log 2$ at 44 days-old.

-B- Specific immune response against Newcastle Disease virus (NDV): The obtained results revealed that there were no significant differences $(P>$ $0.05)$ due to different CDDGS levels. Also, there were no significant differences $(P>0.05)$ for adding Galzym levels to diets. However, there were no significant differences $(P>0.05)$ in the interaction effects of using CDDGS levels with or without Galzym supplementation before and after vaccination time (Table4). These results are in agreement with El-Sayed et al. (2011) who found that there were no significant differences in antibody titer against ND virus of birds vaccinated with $A l+N D$ vaccination program. In other words, birds vaccinated at one day-old recorded higher antibody titer against ND virus at 4 days of age $(6.95 \log 2)$ than birds vaccinated at 7 days of age (6.50 log2). In reality, no physiological effect was detected, because both of them have titer of about $7 \log 2$ which led to the same protection level $100 \%$ as indicted by Tian et al. (2005) and Kumar et al. (2007). On the other hand, the Newcastle disease virus $\mathrm{HI}$ titer values were lower than those obtained by El-sayed et al. (2011). 
Table 4: Effects of dietary CDDGS and Galzym levels on some immunological traits (AIDV) titer and (NDV) titer (before and after vaccination) $(\log 2)$

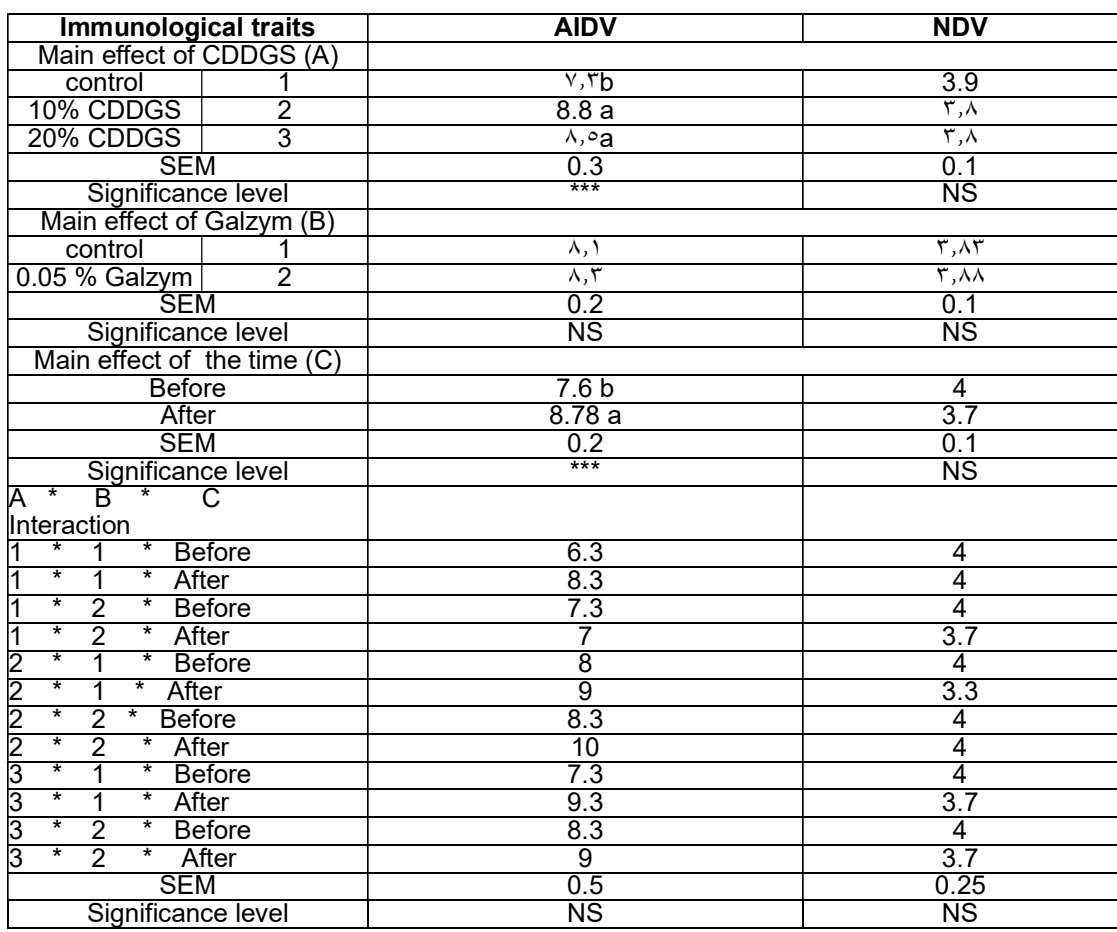

(a-b) means with the same letter in each column in each category are not significantly different at $p \leq 0.05 \quad N S=$ not significant at $P>0.05 \quad$ s** significant at $p \leq 0.001$

\section{Conclusion}

It is concluded that supplementing broiler's diets with $20 \%$ CDDGS with or without Galzym supplementation improved growth performance and blood plasma total protein values but decreased inorganic phosphorus values and insignificantly increased blood plasma total cholesterol as compared to the control samples. The use of CDDGS levels as partial replacement with or without Galzym preparation to broiler diets enhanced the specific immunity against avian influenza disease virus (AIDV) titer values. As well, there were no negative effects on NDV titer values.

\section{REFERENCES}

AL-Bustany, Z. (1996). The effect of pelleting on enzyme supplemented barley based diet. Anim. Feed Sci. Tech., 58: 283-288.

Alexander, D.J. (2000). Newcastle disease and other avian paramyxoviruses. Rev. Sci. Tech. 19:443-462. 
Al-Harthi, M.A. (2006). Impact of supplemental feed enzymes, condiments mixture or their combination on broiler performance, nutrients digestibility and plasma constituents. Inter. J. Poult Sci., 5 (8): 764-771.

Ali, M.N., M.S. Hassan and I.M. Abaza (2006). Effect of improving the utilization of wheat bran on productive and physiological performance for local laying hens. Egypt. Poult. Sci., 26: 137-158.

Allain, C.C., Poon L.S., Chan C.S., Richmond W. and Fu P.C. (1974). Enzymatic determination of total serum cholesterol. Clin. Chem., 20: 470. $2^{\text {nd }} \mathrm{Ed}$. Edited by W.R. Faulkner and S.M. Mietes. Washington, D.C.

Amani W. Youssef, Soha S. Abd El-Magid, A.H. Abd El-Gawad, Eman F. ElDaly and H.M. Ali (2012). Effect of inclusion of distillers dried grains with solubles (DDGS) on the productive performance of growing rabbits. American-Eurasian J. Agric. \& Environ. Sci., 12 (3): 321-326.

AOAC (1984). Official Methods of Analysis, $14^{\text {th }}$ ed. Association of Official Analytical Chemists, Inc. Arlington, Virginia, USA.

Arce, J. Avila, E. Rosales, E. Charraga, S. Fernández, SR. (2010). Effect of adding protease and xylanase feed enzymes activities on broilers fed corn-SBM-DDGS diets. Pro. Inter. Poult. Sci., Atlanta, US. T108.

Augelovicova, M. and I. Michalik (1997). A test of enzymatic preparation in relation to performance and commercial utilization of feeds in broiler chickens. Zivocisna-Vyroba, 42: 175-180.

Awad, A. L., M.A.A. Hussein , A.I.A. Ghonim and M.G. Kasim (2011). Effect of dietary inclusion level of distillers dried grains with solubles on growth performance of domyati ducklings. Egypt Poult. Sci. Vol (31) (I).

Belyea, R.L., Rausch, K.D. and Tumbleson, M.E. (2004). Composition of corn and distillers dried grains with solubles from dry-grind ethanol processing. Biores. Technol. 94:293-298.

Bor-Ling Shih, A-Li Hsu, and Y.K. Chen (2011). Effects of corn distiller's dried grains with soluble on the productive performance and egg quality of laying hens. Division of Nutrition, Livestock Research Institute, Taiwan. Council of Agriculture. AGAPE Nutrition Consultant. http://www.ddgs.umn.edu/International/InternatIResrch/index.htm

Brugh, M. and Stone, H.D. (1986). Immunizing of chickens with haemagglutinin-specific (H5) oil emulsion vaccine. Proceedings of the Second International Symposium on Avian Influenza (pp. 283-292). United States Animal Health Association, Athens, Georgia, USA.

Butzen, S., Haefele D. (2008). Dry-grind ethanol production from corn. Crop Insights, 18: 1-5.

Choi, H. S., Lee H. L., Shin M. H., Cheorun J., Lee S. K. and Lee B. D. (2008). Nutritive and economic values of corn distiller's dried grains with solubles in broiler diets. Asian-Aust. J. Anim. Sci.Vol. 21, No. 3 : $414-419$

Couch, J.R., A.A. Kurnick, R. L. Svacha and B. L. Reid (1957). Effect of distillers solubles and molybdenum on the growing chick. Soc. Exp. Biol. Med. 95:353. 
Cowieson, A.J. (2005). Factors that affect the nutritional value of maize for broilers. Animal Feed Science and Technology 119: 293-305.

Cowieson, A.J. and Ravindran V. (2008a). Effect of exogenous enzymes in maize-based diets varying in nutrient density for young broilers: growth performance and digestibility of energy, minerals and amino acids. British Poultry Science 49: 37-44.

Cowieson, A.J. and Ravindran V. (2008b). Sensitivity of broiler starters to three doses of an enzyme cocktail in maize-based diets. British Poultry Science 49: 340-346.

Cromwell, G. L., K. L. Herkelman and T. S. Stahly (1993). Physical, chemical, and nutritional characteristics of distillers dried grains with solubles for chicks and pigs. J. Anim. Sci. 71:679- 686.

Dale, N. and A. Batal (2003). Nutritional value of distillers dried grains and solubles for poultry. Pages 1-6 in: $19^{\text {th }}$ Annual Carolina Nutrition Conf., Research Triangle Park, NC.

Davis, K.S. (2001). Corn milling, processing and generation of co-products. $62^{\text {nd }}$ Minnesota Nutr. Conf. and Minnesota Corn Growers Association Technical Symposium, Bloomington, MN, pp: 1-7.

Day, E. J., B. C. Dilworth and J. McNaughton (197'12). Unidentified growth factor sources in poultry diets. In "Proceedings Distillers Feed Research Council Conference". Pages 40-45.

Doumas, B.T. (1975). Standards for total serum protein assay. Clin. Chem., 21: 1159.

Duncan, D.B. (1955). Multiple range and multiple F-tests. Biometrics. 11:142.

Ellis, T. M., Barry, B. R., Bissett, L. A., Dyrting, K. C., Luk, G. S., Tsim, S. T., Sturm-Ramirez, K., Webster, R. G., Guan, Y. and Malik Peiris, J. S. (2004). Investigation of outbreaks of highly pathogenic H5N1 avian influenza in waterfowl and wild birds in Hong Kong in late 2002. Avian Pathol. 33:492-505.

El-Sayed, D.A.A., Abdou A.M., Shalash S.M.M., Riad S.A. and Safaa H.M. (2011). Influence of vaccination with different avian influenza vaccines at one or seven days-old on productivity, blood biochemical and immune response of broiler chicks. Egypt. Poult. Sci. Vol (31) (IV): (825-843).

Fastinger, N. D., Latshaw, J. D. and Mahan D.C. (2006). Amino acid availability and true metabolizable energy content of corn distillers dried grains with solubles in adult cecectomized roosters. Poult. Sci., 85: 1212-1216.

Fouchier, R.A., Munster, V., Wallensten, A., Bestebroer, T.M., Herfst, S. Smith, D., Rimmelzwaan, G.F., Olsen, B. and Osterhaus, A.D. (2005). Characterization of a novel influenza A virus hemagglutinin subtype (H16) obtained from black-headed gulls. J. Virol. 79:2814-2822.

Gabr, A.A., Kh. El. Sherif and A.F. Naeem (2008). Effect of inclusion dried distiller's grains with solubles with enzyme addition in rabbit diets on performance, digestibility, carcass traits and some blood constituents. J Agric. Sci. Mansoura Univ., 33: 6335 - 6349. 
Gallili, G.E. and D. Ben-Nathan (1998). Newcastle disease vaccines. Biotechnol. Adv. 16:343-366.

Ghazalah, A.A.; M.O. Abd-Elsamee; A.S. Abd El-Hakim and M.M. Ibrahim (2012). Evaluation of using distiller's dried grains with solubles in broiler diets. Egypt. Poult. Sci. Vol (32) (II): 381-397.

Ghazi, S., Rooke, J. A., Galbraith, H. (2003). Improvement of the nutritive value of soybean meal by protease and $\alpha$-galactosidase treatment in broiler cockerels and broiler chicks. British Poultry Science 44: 410418.

Ghazi, S., Rooke, J. A., Galbraith, H. and Bedford, M. R. (2002). The potential for the improvement of the nutritive value of soya-bean meal by different proteases in broiler chicks and broiler cockerels. British Poultry Science 43: 70-77.

Gurung, N. K., S. G. Solaiman, D. L. Rankins, Jr., and W. H. McElhenney (2009). Feeding performance and blood parameters of male goat kids fed EasiFlo® cottonseed. Small Ruminant Research. 81:137-145.

Hafez, M.H., Arafa A., Abdelwhab E.M., Selim A., Khoulosy S.G., Hassan M.K., Aly M.M. (2010). Avian influenza H5N1 virus infections in vaccinated commercial and backyard poultry in Egypt. Poult. Sci., 89:1609-1613.

Heba Salim (2011). Nutritional, physiological and environmental effects of feeding distiller's grains plus solubles to feedlot cattle. Heba Salim's PhD thesis. Faculty of Graduate Studies, University of Guelph.

Higgins, D.A. (1996). Comparative immunology in avian species. In: T.F. Davison, T.R. Morris and L.N. Payne (Editors), Poultry Immunology, Poultry Science Symposium Series, Vol.24, Carfax Publishing Company, Abingdon, England, pp.149-205.

Hong, D., H. Burrows, O. Adeola (2002). Addition of enzyme to starter and grower diets for ducks. Poultry Science, 8: 1842-1849.

Jia Tse Hoi, Curtis L. Weller, Vicki Schlegel, Susan L. Cuppett, Ji-Young Lee and Timothy P. Carr (2009). Sorghum distillers dried grain lipid extract increases cholesterol excretion and decreases plasma and liver cholesterol concentration in hamsters. University of Nebraska-Lincoln, Journal of Functional Foods;1(4):381-386.

Jiang, Z., Y. Zhou, F. Lu, Z. Han and T. Wang (2008). Effects of different levels of supplementary alpha-amylase on digestive enzyme activities and pancreatic amylase mRNA expression of young broilers. AsianAustralian Journal of Animal Science 21: 97-102.

Kaya Ö. and Tarkan Ş. (2012). Effects of different levels of distillers dried grains with solubles on growth performance, carcass quality and some blood parameters in broilers. This study was produced of Özlem Kaya's Ph.D. thesis and was supported by the Kafkas University Scientifc Research fund commission under the Project No: 2010- VF54.

Kim, J.-K., G. Kayali, D. Walker, H. L. Forrest, A. H. Ellebedy, Y. S. Griffin, A. Rubrum, M. M. Bahgat, M. A. Kutkat, M. A. A. Ali, J. R. Aldridge, N. J. Negovetich, S. Krauss, R. J. Webby and R. G. Webster (2010). The puzzling inefficiency of H5N1 influenza vaccines in Egyptian poultry. 
Proceedings of the National Academy of Sciences of the United States of America 107:11044-11049.

Kim, Y., Mosier, N.S., Hendrickson, R., Ezeji, T., Blaschek, H., Dien, B., Cotta, M., Dale, B., Ladisch, M.R. (2008). Composition of corn drygrind ethanol by-products: DDGS, wet cake, and thin stillage. Biores. Technol. 99,5165-5176.

Kimura, N. (2005). Basic studies on the effect on layer hens of DDGS produced in USA. Chapter30. Summary of U.S. Grains Council Sponsored International Feeding Trials http://www.ddgs.umn.edu/articlespoultry/2005Kirmura\%20Layer\%20he ns\%20trial\%20report\%20summary.pdf

Kumar, M., H. Chu, J. Rodenberg, S. A. Kraus, and R. G. Webster (2007). Association of serologic and protective responses of avian influenza vaccines in chickens. Avian Dis. 51:481-483.

Lebdah, M.A. and A.M. Shahin (2010). Evaluation of avian influenza vaccines used in broiler flocks in Egypt. Journal of American Science, 6 (12):918-926.

Leytem, A.B. and Kwanyuen, P. and Thacker, P.A. (2008). Nutrient excretion, phosphorus characterization and phosphorus solubility in excreta from broiler chicks fed diets containing graded levels of wheat distillers grains with solubles. Poult. Sci., 87: 2505-2511.

Liu, N., Ru, Y.J., Cowieson, A.J., Li, F.D. and Cheng, X.CH. (2008a). Effects of phytate and phytase on the performance and immune function of broilers fed nutritionally marginal diets. Poultry Science 87: 1105-1111.

Liu, N., Ru, Y.J., Li, F.D. and Cowieson, A.J. (2008b). Effect of diet containing phytate and phytase on the activity and mRNA expression of carbohydrase and transporter in chickens. Journal of Animal Science published online on August 15, 2008 as doi: 10.2527/jas.2008-1234.

Lu, J.J. and Y.K. Chen (2005). Effects of feeding diets containing U.S. corn distillers dried grains with solubles on growth performance and carcass quality of domestic colored broiler chickens in Taiwan. Department of Animal Science, National Chia- Yi University and AGAPE Nutrition Consultant. Chapter 30. Summary of U.S. Grains Council Sponsored International Feeding Trials.

Lumpkins, B.S., Batal, A.B. and Dale, N.M. (2004). Evaluation of distillers dried grains with solubles as a feed ingredient for broilers. University of Georgia. Poult. Sci., 83: 1891-1896.

Mancini, M. and M. Parillo (1991). Lipid intake and therosclerosis. Ann. Nutr. Metab. 35: 103-108.

Martinez-Amezcua, C., C.M. Parsons and S.L. Noll. (2004). Constant and relative bioavailability of phosphorus in distillers dried grains with solubles in chicks. Poult. Sci., 83 (6): 971-976.

Masadeh, M. K., C. A. Fassbinder-Orth; and S. E. Scheideler (2010). High dietary inclusion of dried distillers grains with solubles in broiler chick rations in combination with AllzymeSSF enzyme- effects on yield and endogenous enzyme levels. Poultry Sci. 89:Abstracts. 
Tork, M. I. Dorra et al.

Mathlouthi, N., Saulnier, L., Quemener, B. and Larbier, M. (2002). Xylanase, $\beta$ - glucanase, and other side enzymatic activities have greater effects on viscosity of several feedstuffs than xylanase or $\beta$-glucanase used alone or in combination. Journal of Agricultural and Food Chemistry 50: 5121-5127.

Meng, X., Slominski, B.A., Nyachoti, C.M., Campbell, C.M. and Guenter, W. (2005). Degradation of cell wall polysaccharides by combinations of carbohydrase enzymes and their effect on nutrient utilization and broiler chicken performance. Poultry Science 84: 37-47.

Noll, S.L. and J. Brannon (2006). Inclusion levels of corn distillers grains with solubles and poultry byproduct meal in market turkey diets. Poult. Sci., 85 (Suppl. 1): 106-107.

Noll, S. L. C. Parsons and William Dozier, III (2007). Formulating poultry diets with DDGS - How far can we go? In "Proceedings $5^{\text {th }}$ Mid-Atlantic Nutrition Conference" Maryland Feed Industry Council and Cooperators. Ed. N. G. Zimmermann, University of Maryland. Pages 91-99.

Onifade, A.A. and G.M. Babatunde (1998). Comparison of the utilization of palm kernel meal, brewers dried grains and maize offal by broiler chicks. Br. Poult. Sci., 39: 245- 250.

Onyango, E. M., M. R. Bedford and O. Adeola (2005). Efficacy of an evolved Escherichia coli phytase in diets of broiler chicks. Poultry Science 84: 248-255.

Pack, M., M. Bedford and C. Wyatt (1998). Feed enzymes may improve corn, sorghum diet. Feedstuffs 2 (Feb.): 18-19.

Parsons, C.M., D. H. Baker and J. M. Harter (1983). Distillers dried grains with solubles as a protein source for the chick. Poult. Sci., 62: 24452451.

Pettersson, D. and Åman, P. (1992). Production responses and serum lipid concentration of broiler chickens fed diets based on oat bran and extracted oat bran with and without enzyme supplementation. J. Sci Food Agric 58: 569-576.

Peyre M.I., Samaha H., Saad A., Abd-Elnabi A., Galal S., Ettel T., Dauphin G., Lubroth J., Roger F., Domenech J. (2009). Avian influenza vaccination in Egypt: limitations of the current strategy. Journal of Molecular and Genetic Medicine 3(2):198-204.

Potter, L.M. (1966). Studies with distillers feeds in turkey rations. Proc. Distillers Res. Conf., 21: 47-51.Cincinnati $\mathrm{OH}$.

Qota, E.M.A., A.A. EL-Ghamry and G.M. EL-Mallah (2002). Nutritive value of soaked linseed cake as affected by phytase, biogen supplementation or formulating diets based on a available amino acid on broiler performance. Egypt. Poult. Sci, 22 (II) : 461-475.

Richter, G., M. Schurz, W. I. Ochrimenko, H. Kohler, R. Schubert, R. Bitsch and G. Jahrais (1999). The effect of NSP-hydrolyzing enzymes in diets of laying hens and broilers. Vitamine and Zusatzstoffe in der Ernahrung von Mensch Und Tier: 7 Symposium Jena-Thuringen, Germany, pp: 519-522. 
Ritz, C.W., Hulet R.M., Self B.B. and Denbow D.M. (1995). Growth and intestinal morphology of male turkeys as influenced by dietary supplementation of amylase and xylanase. Poul. Sci. 74: 1329-1334.

Salobir, J., A. Kermauner, C. Bogdanic, A. Malensek, J. Stopar and M. Struklec (1995). Effect of enzyme preparation polizyme R-BX on the performance and intestinal viscosity of broiler chickens fed wheat and maize/wheat based diets. Zootecnica- International, 19: 82-85.

SAS Institute Inc.(1990). SAS/STAT User's Guide Release 6.08. SAS Institute Inc., Cary, NC.

Shakmak, S. (2003). Improvement of productive performance in poultry. M. sc. thesis, Faculty of agriculture, Poultry Production Department, Mansoura University, Egypt.

Shalash, S.M.M., M.N. Ali, M.A.M. Sayed, Hoda E. El-Gabry and M. Shabaan (2009). Novel method for improving the utilization of corn dried distiller's grains with solubles in broiler diets. Inter. J. of Poult. Sci. 8: 545-552.

Shurson, J. (2003). The value and use of distillers dried grains with solubles DDGS in livestock and poultry rations. http://www.ddgs.umn.edu/. Accessed Jan. 2005.

Sidney, P.G. and R. Barnard (1973). Improved manual spectrophotmetric procedure for determination of serum triglycerides. Clin. Chem., 19: 1077-1078.

Spiehs, M.J., M.H. Whitney and G.C. Shurson (2002). Nutrient database for distiller's dried grains with solubles produced from new ethanol plants in Minnesota and South Dakota. J. Anim. Sci., 80:2639-2645.

Sutton, C.D., W.M. Muir and G.E.J. Mitchell (1985). The effect of dietary cholesterol, energy intake and oxygen consumption on cholesterol metabolism in the chick. Poult. Sci., 64: 502-509.

Swayne, D.E. (2009). Avian influenza vaccines and therapies for poultry. Comp. Immunol. Microbiol. Infect. Dis. 32:351-363.

Swayne, D.E. and D.J. King (2003). Avian influenza and Newcastle disease. J. Am. Vet. Med. Assoc. 222:1534-1540.

Swayne, D.E. and D.L. Suarez (2000). Highly pathogenic avian influenza. Rev. Sci. Tech. 19:463-482.

Swayne, D.E., Suarez D.L., Schultz-Cherry S., Tumpey T.M., King D.J., Nakaya T., Palese P., Garcia-Sastre A. (2003). Recombinant paramyxovirus type 1-avian influenza- $\mathrm{H} 7$ virus as a vaccine for protection of chickens against influenza and Newcastle disease. Avian Dis. 47:1047-1050.

Swiatkiewicz, S. and Koreleski J. (2008). The use of distillers dried grains with solubles (DDGS) in poultry nutrition. World's Poult. Sci. J., 64: 257-266.

Tanaka, M., Y. Kamiya, T. Suzuki, M. Kamiya and Y. Nakai (2008). Relationship between milk production and plasma concentrations of oxidative stress markers during hot season in primiparous cows. Animal Science Journal. 79:481-486. 
Tork, M. I. Dorra et al.

Tian, G., Zhang S., Li Y., Bu Z., Liu P., Zhou J., Li C., Shi J., Yu K. and Chen $H$. (2005). Protective efficacy in chickens, geese and ducks of an H5N1-inactivated vaccine developed by reverse genetics 6 . Virology 341:153-162.

Viveros, A., Brenes A., Arija I., Centeno C. (2002). Effects of microbial phytase supplementation on mineral utilization and serum enzyme activities in broiler chicks fed different levels of phosphorus. Poult. Sci., 81: 1172-1183.

Vranjes, M.V., Pfirter, H.P. and Wenk, C. (1994). Influence of processing treatment and type of cereal on the effect of dietary enzymes in broiler diets. Animal Feed Science and Technology 46: 261-270.

Waldroup, P.W., Owen J.A., Ramsey B.L., Whelchel D.L. (1981). The use of high levels of distillers dried grains with solubles in broiler diets. Poult. Sci., 60: 1479-1484.

Wang, H., Guo, Y. and Shih, J.C.H. (2008). Effects of dietary supplementation of keratinase on growth performance, nitrogen retention and intestinal morphology of broiler chickens fed diets with soybean meal and cottonseed meal. Animal Feed Science and Technology 140: 376-384.

Wang, Z., S. Cerrate, C. Coto, F. Yan and P.W. Waldroup (2007). Evaluation of high levels of Distillers Dried Grains with Solubles (DDGS) in broiler diets. Int. J. Poult. Sci., 7: 990-996.

Wang, Z., S. Cerrate, C. Coto, F. Yan and P.W. Waldroup (2007a). Utilization of distillers dried grains with solubles DDGS in broiler diets using a standardized nutrient matrix. Inter. J. Poult. Sci. $6: 470-477$.

Wang, Z., S. Cerrate, C. Coto, F. Yan and P.W. Waldroup (2007b). Use of constant or increasing levels of distillers dried grains with solubles DDGS in Broiler Diets. Inter. J. Poult. Sci. $7:$ 501-507.

Wang, Z., S. Cerrate, C. Coto, F. Yan and P.W. Waldroup (2007c). Effect of rapid and multiple changes in level of distillers dried grain with soluble (DDGS) in broiler diets on performance and carcass characteristics. Int. J. Poult. Sci., 6: 725-731.

Widyaratne, G. P. and R. T. Zijlstra (2007). Nutritional value of wheat and corn distillers dried grain with solubles: digestibility and digestible contents of energy, amino acids and phosphorus, nutrient excretion and growth performance of grower-finisher pigs. Can. J. Anim. Sci. 87:103-114.

World Health Organization (2010). H5N1 avian influenza: timeline of major events reported to WHO (World Health Organization, Geneva, Switzerland).

Wyatt, C., M. Soto-Salanova and M. Pack (1997). Applying enzymes to sorghum-based diets. Pages116-118 in: Proceedings of Aust. Poult. Sci. Symp. 9. Sydney, Australia.

Youssef, I.M., Westfahl C., Sünder A., Liebert F., Kamphues J. (2008). Evaluation of distillers' dried grains with solubles DDGS as a protein source for broilers. Arch. Anim. Nut., Volume 62: 404-414. 
Zanella, I., Sakomura N.K., Silversides F.G., Fiqueirdo A., Pack M. (1999). Effect of enzyme supplementation of broiler diets based on corn and soybeans. Poultry Science 78: 561-568.

\section{تـأثير استخدام نـواتج تقطير حبوب الأذرة المجففة بالمـذيبات مـع أو بـدون إضـافة

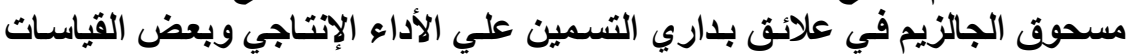

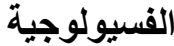

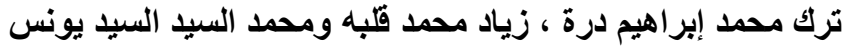

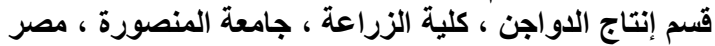

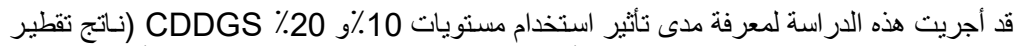

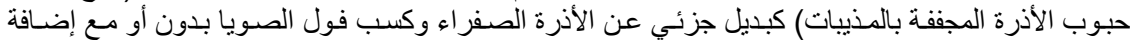

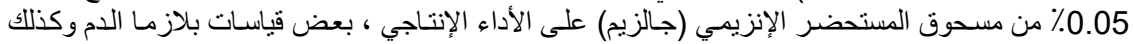

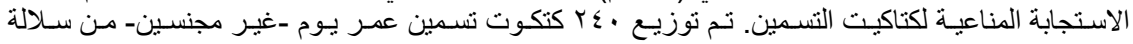
Cobb 500

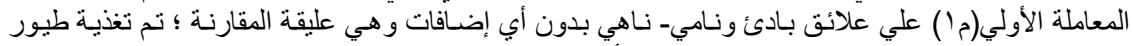

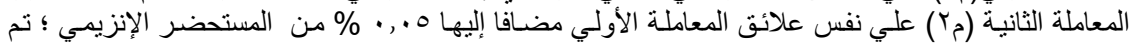

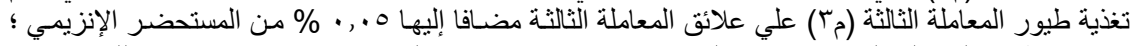

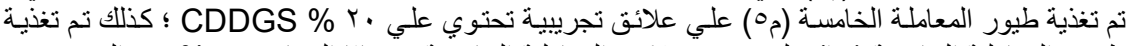

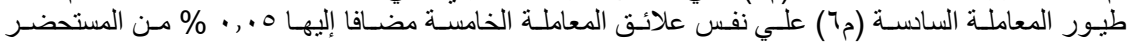

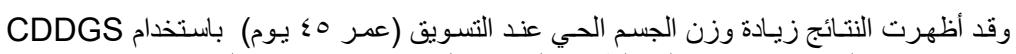

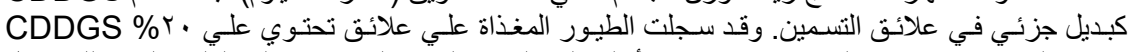

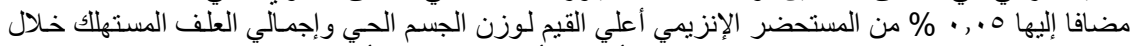

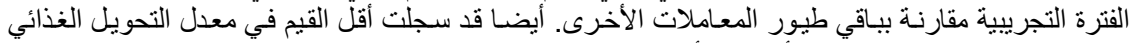

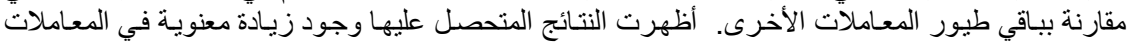

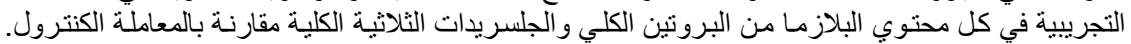

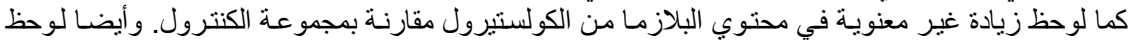

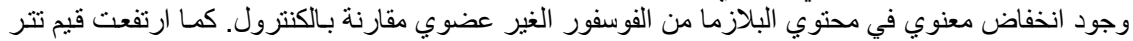

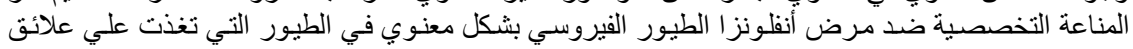

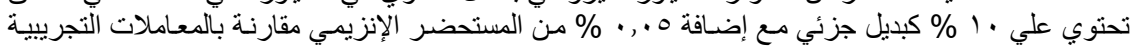

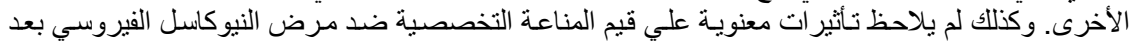
التحصين بين جميع المعاملات التجريبية.

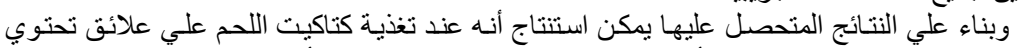

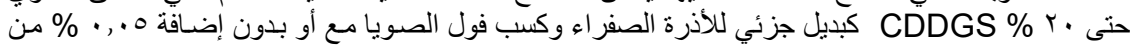

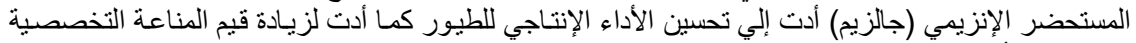

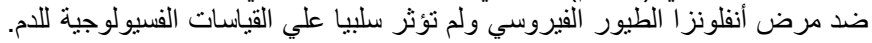

كلية الزراعة - جامعة المنصورة كليةً الزراعة - جامعة عين شمس الزمس

\author{
قام بتدكيم البحث \\ أ.د / خليل الثحات شريف

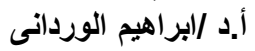


Tork, M. I. Dorra et al. 